\title{
The roles of tropical and subtropical wind stress anomalies in the EI Niño Modoki onset
}

\author{
Xin Wang ${ }^{1,2}$ (1) $\cdot$ Chengyang Guan ${ }^{1,3} \cdot$ Rui Xin Huang ${ }^{4} \cdot$ Wei Tan $^{2,5} \cdot$ Lei Wang $^{6}$
}

Received: 14 January 2018 / Accepted: 12 November 2018 / Published online: 17 November 2018

(c) The Author(s) 2018

\begin{abstract}
The El Niño Modoki is separated into two types, El Niño Modoki I and El Niño Modoki II, which are characterized by substantially different mechanism. According to comparisons between the evolution of air-sea coupled processes and heat budget analyses, this study discovered the distinct dynamical mechanism of the onset of El Niño Modoki II compared to that of El Niño Modoki I. For El Niño Modoki I, westerly wind anomalies in the western Pacific appear earlier than warm sea surface temperature (SST) anomalies in the central tropical Pacific; in addition, zonal advection is responsible for changes in mixed-layer temperature in the Niño-4 region during the developing phase in spring and summer. However, warm SST anomalies accompany easterly anomalies in the central tropical Pacific, and there are no westerly anomalies in the western tropical Pacific during the developing phase in spring and summer for El Niño Modoki II. For El Niño Modoki II, Ekman feedback is the major contributor to changes in mixed-layer temperature. According to reanalysis data, the 2.5-layer model results and coupled model simulations, anomalous westerly wind stress in the subtropical North Pacific and easterly wind stress in the central-eastern tropical Pacific can lead to equatorward and westward oceanic current anomalies, thus enhancing meridional and zonal convergences at upper layer. Because anomalous convergence at upper layer can inhibit upwelling motion in the central tropical Pacific, SST anomalies in the central tropical Pacific tend to be warm, even without anomalous westerlies in the western Pacific.
\end{abstract}

Keywords El Niño Modoki · Ekman feedback · Northern subtropical Pacific

\section{Introduction}

\section{Xin Wang}

wangxin@scsio.ac.cn

1 State Key Laboratory of Tropical Oceanography, South China Sea Institute of Oceanology, Chinese Academy of Sciences, 164 West Xingang Rd., Guangzhou 510301, China

2 Laboratory for Regional Oceanography and Numerical Modeling, Qingdao National Laboratory for Marine Science and Technology, Qingdao, China

3 University of Chinese Academy of Sciences, Beijing, China

4 Woods Hole Oceanographic Institution, Woods Hole, MA 02543, USA

5 First Institute of Oceanography, State Oceanic Administration, Qingdao, China

6 Guangdong Province Key Laboratory for Coastal Ocean Variation and Disaster Prediction, Department of Oceanography, College of Ocean and Meteorology, Guangdong Ocean University, Zhanjiang, China
Recent studies suggest that there exist two types of El Niño events: canonical El Niño and El Niño Modoki (Trenberth and Stepaniak 2001; Larkin and Harrison 2005; Ashok et al. 2007; Yu and Kao 2007; Kao and Yu 2009; Kug et al. 2009). During a canonical El Niño, also referred to as the eastern Pacific El Niño, anomalously warm sea surface temperatures (SSTs) are centered at the cold-tongue region in the eastern tropical Pacific. During an El Niño Modoki, also referred to as the dateline El Niño (Larkin and Harrison 2005), or central Pacific El Niño (Yu and Kao 2007), warm SST anomalies are located in the central tropical Pacific. It is noted that El Niño Modoki proposed by Ashok et al. (2007) exhibits dipole-like SST anomalies in the central-eastern tropical Pacific, which is different from warm pool El Niño (Kug et al. 2009). Lian and Chen (2012) suggested that such dipole-like mode of SST anomalies results from the orthogonality constraint of the EOF analysis, and can not represent the real pattern. Regarding these two types of El 
Niño events, not only are the distributions and evolutions of SST anomalies different, but the impacts on global climate are also different (Kumar et al. 2006; Ashok et al. 2007; Taschetto and England 2009; Weng et al. 2011; Wang et al. 2013, 2014; Liu et al. 2014; Xu et al. 2018). Studies on the El Niño Modoki have attracted an increasing amount of attention (Capotondi et al. 2015; Yu et al. 2017).

Different mechanisms have been proposed to explain the occurrence of El Niño Modoki (Ashok et al. 2007; Kug et al. 2009; Yu et al. 2010; Chen et al. 2015; Lai et al. 2015). Ashok et al. (2007) suggested that warming in the central Pacific is due to deepening of the thermocline, which is related to eastward-propagating down-welling Kelvin waves induced by westerly anomalies in the western equatorial Pacific and westward-propagating down-welling Rossby waves induced by easterly anomalies in the eastern equatorial Pacific (Bjerknes 1969). Kug et al. (2009) noted that wind-driven thermocline variations may not be adequate for producing SST anomalies seen in an El Niño Modoki because the mean thermocline is relatively deep in the central Pacific. Instead, they argued that warming in the central tropical Pacific develops mainly from oceanic advection, and warming in the eastern tropical Pacific is suppressed due to enhanced upwelling and evaporation caused by equatorial easterly anomalies. Yu et al. (2010) emphasized the effects of oceanic advection on the anomalously warm SST in the central tropical Pacific. They stated that SST anomalies first emerge in the northeastern subtropical Pacific, then spread to the central equatorial Pacific through wind-evaporation-SST (WES) feedback (Xie and Philander 1994). Chen et al. (2015) concluded that warm water volume (WWV) and westerly wind bursts (WWBs) in the equatorial Pacific work together to generate the diverse El Niño events. Lai et al. (2015) reported that the diversity of El Niño events is a joint result of zonal wind anomalies in the central-western Pacific $\left(140^{\circ} \mathrm{E}-160^{\circ} \mathrm{W}\right)$ during the developing year and subsurface temperature anomalies in the western Pacific during the previous winter. Their study showed that cumulative zonal wind anomalies are more decisive than WWBs.

Wang and Wang (2013) discovered that El Niño Modoki events can be classified into two types, El Niño Modoki I and El Niño Modoki II, and postulated an index to identify them (Wang et al. 2018). SST anomalies during El Niño Modoki I first appear in the central equatorial Pacific and develop locally, whereas SST anomalies during El Niño Modoki II first appear in the northeastern subtropical Pacific, which later spread towards and peak in the central equatorial Pacific. These two types of El Niño Modoki events show distinct features in SST warming position and regional climatic effects (Wang and Wang 2013, 2014; Tan et al. 2016). From the observation and model results, El Niño Modoki I results in anticyclone circulation anomalies in the Philippine Sea in developing autumn via Rossby wave responses, while El Niño
Modoki II induces cyclone circulation anomalies in the east of the Philippines (Wang and Wang 2013; Wang et al. 2018). The anomalous anticyclone (cyclone) circulations associated with El Niño Modoki I (El Niño Modoki II) can thus lead to the increase (decrease) of rainfall in southern China. Wang and Wang (2014) demonstrated that the weakening of the Walker circulation in the Indo-Pacific during the canonical El Niño and El Niño Modoki I is in favor of a positive Indian Ocean Dipole (IOD), the mode that is argued independent of ENSO (Saji et al. 1999). On the other hand, the Walker circulation is enhanced during El Niño Modoki II, and thus tends to induce a negative IOD. Moreover, a weakly positive IOD in 2015 is suggested to be associated with El Niño Modoki II (Liu et al. 2017). Tan et al. (2016) showed that during the developing fall, SSTs in the South China Sea (SCS) exhibit negative (positive) anomalies during El Niño Modoki II (canonical El Niño and El Niño Modoki I). They suggested that it is the different position of the anomalous anticyclone in the western Pacific that results in distinct latent heat flux anomalies in the SCS, which creates opposite SST variations.

As shown in previous studies, climate impacts of El Niño Modoki II are distinctly different from those of canonical El Niño and El Niño Modoki I. However, the air-sea coupled preconditions and onset mechanisms of El Niño Modoki II remain unknown. Thus, the goal of this study is to examine the mechanism of El Niño Modoki II events. This paper is organized as follows. Section 2 introduces the datasets, methods and models used in this study. Air-sea coupled evolutions and a mixed-layer heat budget analysis during the developing phase of El Niño Modoki I and II events are compared in Sect. 3. In Sect. 4, the roles of ocean dynamics associated with wind stress anomalies in the subtropical and tropical Pacific during the El Niño Modoki II onset are addressed based on reanalysis datasets, the 2.5-layer model and coupled model results. Section 5 presents the summary and discussion.

\section{Datasets and methods}

\subsection{Datasets}

Oceanic current and temperature data from the Simple Ocean Data Assimilation (SODA) 2.2.4 (Carton and Giese 2008; Giese and Ray 2011) and surface heat flux data from the Twentieth Century Global Reanalysis Version 2 (20CR v2; provided by the NOAA/OAR/ESRL PSD at https://www.esrl.noaa.gov/ psd/) (Compo et al. 2011) are utilized. The SODA 2.2.4 dataset has a horizontal resolution of $0.5^{\circ} \times 0.5^{\circ}$ and 40 unevenly distributed vertical levels (resolution ranges from $5 \mathrm{~m}$ near the surface to $250 \mathrm{~m}$ at an approximate $5000 \mathrm{~m}$ depth). The $20 \mathrm{CR}$ v2 data are on a global T62 Gaussian grid. Wind stress fields are taken from SODA 2.2.4. Sea surface wind data are also obtained from the 20CR v2 dataset. SST data are from the Met 
Office Hadley Centre's sea ice and sea surface temperature (HadISST1) dataset with a resolution of $1^{\circ} \times 1^{\circ}$ (Rayner et al. 2003). These monthly atmospheric and oceanic variables cover the period of 1911-2010. Anomalies presented in this paper are the deviation from the monthly mean climatology of the last 30 years (1981-2010). The reanalysis data may have their own uncertainties, but we found that these conclusions are insensitive to the selection of datasets or time ranges. Consistent results can be achieved using other reanalysis datasets with different time ranges (e.g., NCEP Global Ocean Data Assimilation System reanalysis data). In addition, monthly potential temperature and potential density from Levitus94 (Levitus and Boyer 1994) are applied for the calculation of model parameters.

\subsection{Heat budget analysis of mixed-layer temperature}

The equation for the mixed-layer temperature heat budget (Huang et al. 2010) is

$\mathrm{T}_{t}=Q_{u}+\mathrm{Q}_{v}+Q_{w}+\mathrm{Q}_{q}+\mathrm{R}$

where the temperature tendency $\left(\mathrm{T}_{t}\right)$ is decomposed into five terms, including zonal advection $\left(\mathrm{Q}_{\mathrm{u}}\right)$, meridional advection $\left(Q_{v}\right)$, vertical advection $\left(Q_{w}\right)$, net surface heat flux $\left(Q_{q}\right)$ and the residuals $(\mathrm{R})$. These terms are defined as:

$\mathrm{T}_{t}=\partial \mathrm{T} / \partial \mathrm{t}$

$\mathrm{Q}_{\mathrm{u}}=-\mathrm{u} \partial \mathrm{T} / \partial \mathrm{x}$

$\mathrm{Q}_{\mathrm{v}}=-\mathrm{v} \partial \mathrm{T} / \partial \mathrm{y}$

$\mathrm{Q}_{\mathrm{w}}=-\mathrm{w}_{\mathrm{e}} \partial \mathrm{T} / \partial \mathrm{z}$

$\mathrm{Q}_{\mathrm{q}}=\mathrm{Q}_{\mathrm{net}} / \rho \mathrm{c}_{\mathrm{p}} \mathrm{h}$.

Here, $\mathrm{T}$ is the mixed-layer temperature, and $\mathrm{T}_{t}$ is based on backward time difference (e.g., $\mathrm{T}_{t}($ May $)=T($ May $)-T($ April $)$ ). $\mathrm{u}, \mathrm{v}$, and $\mathrm{w}$ represent the zonal, meridional and vertical velocity, respectively. $w_{e}$ is the entrainment velocity below the mixed layer $\left(\mathrm{w}_{\mathrm{e}}=\frac{\partial \mathrm{h}}{\partial \mathrm{t}}+\mathrm{u}_{-\mathrm{h}} \cdot \frac{\partial \mathrm{h}}{\partial x}+\mathrm{v}_{-\mathrm{h}} \cdot \frac{\partial \mathrm{h}}{\partial y}+\mathrm{w}_{-\mathrm{h}}\right.$, written as $w$ here after), $\rho$ is the water density, $c_{p}$ is the specific heat capacity of sea water under constant pressure, and $\mathrm{h}$ is the depth of the mixed layer.

By decomposing Eq. (1) into climatology and its anomaly, we obtain the following Eq. (7) for anomalous temperature

$\mathrm{T}_{\mathrm{t}}^{\prime}=\mathrm{Q}_{\mathrm{u}}^{\prime}+\mathrm{Q}_{\mathrm{v}}^{\prime}+\mathrm{Q}_{\mathrm{w}}^{\prime}+\mathrm{Q}_{\mathrm{q}}^{\prime}+\mathrm{R}$

where the prime symbols indicate monthly anomalies. Using the overbar to refer to climatology, the terms on the right side of the equation can be written as

$$
\mathrm{Q}_{\mathrm{u}}^{\prime}=-\overline{\mathrm{u}} \frac{\partial \mathrm{T}^{\prime}}{\partial \mathrm{x}}-\mathrm{u}^{\prime} \frac{\partial \overline{\mathrm{T}}}{\partial \mathrm{x}}-\mathrm{u}^{\prime} \frac{\partial \mathrm{T}^{\prime}}{\partial \mathrm{x}}-\overline{\mathrm{u}^{\prime} \frac{\partial \mathrm{T}^{\prime}}{\partial \mathrm{x}}}
$$

$$
\begin{aligned}
& \mathrm{Q}_{\mathrm{v}}^{\prime}=-\overline{\mathrm{v}} \frac{\partial \mathrm{T}^{\prime}}{\partial \mathrm{y}}-\mathrm{v}^{\prime} \frac{\partial \overline{\mathrm{T}}}{\partial \mathrm{y}}-\mathrm{v}^{\prime} \frac{\partial \mathrm{T}^{\prime}}{\partial \mathrm{y}}-\overline{\mathrm{v}^{\prime} \frac{\partial \mathrm{T}^{\prime}}{\partial \mathrm{y}}} \\
& \mathrm{Q}_{\mathrm{w}}^{\prime}=-\overline{\mathrm{w}} \frac{\partial \mathrm{T}^{\prime}}{\partial \mathrm{z}}-\mathrm{w}^{\prime} \frac{\partial \overline{\mathrm{T}}}{\partial \mathrm{z}}-\mathrm{w}^{\prime} \frac{\partial \mathrm{T}^{\prime}}{\partial \mathrm{z}}-\overline{\mathrm{w}^{\prime} \frac{\partial \mathrm{T}^{\prime}}{\partial \mathrm{z}}}
\end{aligned}
$$

and

$\mathrm{Q}_{\mathrm{q}}^{\prime}=\frac{\mathrm{Q}_{\mathrm{net}}^{\prime}}{\rho \mathrm{c}_{\mathrm{p}} \mathrm{h}}$.

Monthly data are used to calculate the heat budget terms. Several sub-monthly processes that might affect the heat balance, such as tropical instability waves, cannot be sufficiently resolved. However, heat budget analyses based on monthly data have been widely utilized and are adequate for the diagnosis of ENSO (Zhang et al. 2007; Huang et al. 2010; Kug et al. 2010; Graham et al. 2017).

\subsection{5-layer ocean model}

A 2.5-layer ocean model (Huang 1987a, b) is used to explore the dynamic influence of wind stress anomalies on the tropical ocean. The 2.5-layer model simplifies the ocean into a rectangular basin with three layers. The first and second layers represent water in the mixed layer and the thermocline, respectively. The bottom layer is assumed to be infinitely deep and motionless. There is no water mixing between each layer.

The momentum and continuity equations for the first and second layers are

$$
\begin{aligned}
- & f h_{1} v_{1}=-\left(g_{1}^{\prime}+g_{2}^{\prime}\right) h_{1} h_{1 x}-g_{2}^{\prime} h_{1} h_{2 x}-k_{1}\left(u_{1}-u_{2}\right) \\
& +A_{m} \nabla\left(h_{1} \nabla u_{1}\right)+\tau / \rho_{0} f h_{1} u_{1}=-\left(g_{1}^{\prime}+g_{2}^{\prime}\right) h_{1} h_{1 y} \\
- & g_{2}^{\prime} h_{1} h_{2 y}-k_{1}\left(v_{1}-v_{2}\right)+A_{m} \nabla\left(h_{1} \nabla v_{1}\right)-f h_{2} v_{2}= \\
- & g_{2}^{\prime} h_{2} h_{1 x}-g_{2}^{\prime} h_{2} h_{2 x}+k_{1}\left(u_{1}-u_{2}\right)-k_{2} u_{2} \\
+ & A_{m} \nabla\left(h_{2} \nabla u_{2}\right) f h_{2} u_{2}=-g_{2}^{\prime} h_{2} h_{1 y}-g_{2}^{\prime} h_{2} h_{2 y} \\
+ & k_{1}\left(v_{1}-v_{2}\right)-k_{2} v_{2}+A_{m} \nabla\left(h_{2} \nabla v_{2}\right) \\
& h_{1 t}+\left(h_{1} u_{1}\right)_{x}+\left(h_{1} v_{1}\right)_{y}=0 \\
& h_{2 t}+\left(h_{2} u_{2}\right)_{x}+\left(h_{2} v_{2}\right)_{y}=0
\end{aligned}
$$

where $f$ is the Coriolis parameter (for a symmetric twohemisphere model, $f=\beta(y-L / 2)$, where $\mathrm{L}$ is the meridional extent of the basin), $h_{1}$ and $h_{2}$ are the layer thickness of the first and second layer, respectively, $\left(u_{1}, v_{1}\right)$ and $\left(u_{2}, v_{2}\right)$ are the horizontal velocity of each layer, $\mathrm{g}_{1}^{\prime}$ and $\mathrm{g}_{2}^{\prime}$ are the reduced gravities, $k_{1}$ and $k_{2}$ are the vertical friction coefficients (both set to $0.0015 \mathrm{~m} / \mathrm{s}$ ), $A_{m}$ is the momentum mixing coefficient along the isopycnal surface (set to $1.5 \times 10^{4} \mathrm{~m}^{2} / \mathrm{s}$ ), and $\tau$ is the zonal wind forcing. Subscripts $t, x$ and $y$ denote the time, zonal and meridional partial derivatives, respectively. 
The domain in the model simulation is set to $\left(40^{\circ} \mathrm{S}-40^{\circ} \mathrm{N}\right.$, $120^{\circ} \mathrm{E}-103^{\circ} \mathrm{W}$ ), with a horizontal grid of $138 \times 82$ (grid size set to $111 \mathrm{~km}$, about $1.0^{\circ} \times 1.0^{\circ}$ resolution). The thicknesses of the first and second layers of the model, and the corresponding reduced gravity coefficients, are calculated from long-term mean monthly data from Levitus94. The primary domain for El Niño events is the tropical Pacific, and thus the layer thicknesses and reduced gravities are calculated as the mean value in the tropical Pacific $\left(30^{\circ} \mathrm{S}-30^{\circ} \mathrm{N}\right.$, $\left.100^{\circ} \mathrm{E}-80^{\circ} \mathrm{W}\right)$. The sum of the first and second thicknesses, which represents the depth of the thermocline, is defined as the depth of the $20^{\circ} \mathrm{C}$ isotherm. The depth of the mixed layer is defined as the depth where the water temperature is $0.5{ }^{\circ} \mathrm{C}$ below the sea surface temperature (Sprintall and Tomczak 1992). Following the above definitions, the depths for the mixed layer and the thermocline from Levitus 94 are $66 \mathrm{~m}$ and $151 \mathrm{~m}$, respectively. For simplicity, the initial thickness of the first layer is set as $\mathrm{H}_{1}=65 \mathrm{~m}$, and the initial thickness of the second layer is set as $\mathrm{H}_{2}=85 \mathrm{~m}$. The reduced gravities of the two layers are calculated as

$\mathrm{g}_{1}^{\prime}=\mathrm{g} \times\left(\rho_{2}-\rho_{1}\right) / \rho_{0}$

$\mathrm{g}_{2}^{\prime}=\mathrm{g} \times\left(\rho_{3}-\rho_{2}\right) / \rho_{0}$

where $\mathrm{g}$ is the gravity acceleration, $\rho_{1}$ is the density of the first layer, $\rho_{2}$ is the density of the second layer, and $\rho_{3}$ is the density of the bottom layer. The results are $\mathrm{g}_{1}^{\prime}=0.015 \mathrm{~m} / \mathrm{s}^{2}$ and $\mathrm{g}_{2}^{\prime}=0.026 \mathrm{~m} / \mathrm{s}^{2}$.

\subsection{Coupled model}

The Community Earth System Model version 1 (CESM1, Hurrell et al. 2013) is used to further investigate how the subtropical wind stress anomalies induce the anomalous warm SST in the equatorial Pacific. CESM1 includes coupled atmosphere, ocean, land and sea ice components, all with horizontal resolution of about $1^{\circ}$. The atmospheric component, the Community Atmosphere Model version 5 (CAM5, Neale et al. 2012), consists of 30 vertical layers. The oceanic component, the Parallel Ocean Program version 2 (POP2, Smith et al. 2010), is with 60 vertical layers. In the study, a fully coupled running with pre-industrial conditions is firstly conducted. The model is running 1200 years to reach the stable.

\section{Comparison of evolutions for two types of El Niño Modoki}

According to Wang and Wang (2013), El Niño Modoki I (El Niño Modoki II) is identified if there are positive (negative) rainfall anomalies in southern China during boreal autumn.
Seven El Niño Modoki I (1914, 1940, 1941, 1963/1964, 1987/1988, 1990/1991, and 2002/2003) and five El Niño Modoki II events (1968/1969, 1979/1980, 1991/1992, 2004/2005, and 2009/2010) are analyzed in this study. Different from the definition in Wang and Wang (2013), the 1992/1993 El Niño Modoki II is excluded because its warming peak is not in winter. Wang and Wang (2013) illustrated the evolutions of SST anomalies from developing spring (March-April-May, MAM) to the following winter (December-January-February, DJF) during El Niño Modoki I and El Niño Modoki II, respectively. For El Niño Modoki I, warm SST anomalies appear in the central equatorial Pacific, then develop and peak in boreal winter. However, for El Niño Modoki II, anomalously warm SSTs appear in the northern subtropical Pacific in boreal spring, then extend towards the tropics, and peak in the central equatorial Pacific in winter. In addition to the differences in warm SST anomaly spatial patterns, this study further illustrates that the evolution of air-sea interactions in the tropical Pacific during El Niño Modoki II is distinct from that during El Niño Modoki I.

Figure 1 displays the evolutions of composited sea surface wind and SST anomalies in the equatorial Pacific during the development of El Niño Modoki I and El Niño Modoki II, as well as their differences. For El Niño Modoki I, the westerly anomalies first appear in the western equatorial Pacific between $135^{\circ} \mathrm{E}-165^{\circ} \mathrm{E}$ during early spring and are accompanied by warm SST anomalies in the central equatorial Pacific (Fig. 1a). Such strong westerly anomalies persist into the developing boreal summer and autumn, and are accompanied by prominently warm SST anomalies (warmer than $0.5^{\circ} \mathrm{C}$ ) in the central and eastern equatorial Pacific. Previous studies have noted that WWBs can trigger downwelling Kelvin waves at the equator, and advect warm surface water eastward and favor the development of El Niño Modoki events (Hu et al. 2014; Lian et al. 2014; Chen et al. 2015; Fedorov et al. 2015; Lai et al. 2015). It is suggested that the onset of El Niño Modoki I is closely associated with air-sea interactions in the tropical Pacific. However, for El Niño Modoki II, there are warm SST anomalies in the central tropical Pacific in developing spring although the intensity is weak, but the westerly anomalies are not seen in the western Pacific until developing summer (Fig. 1b). The easterly anomalies appear between $180^{\circ} \mathrm{E}$ and $120^{\circ} \mathrm{W}$ during the developing earlier spring, with warm SST anomalies in the central tropical Pacific. It seems that the warm SST anomalies in the central tropical Pacific occur earlier than the anomalous westerly in the western tropical Pacific in El Niño Modoki II, which is different from that in El Niño Modoki I. Figure 1c illustrates the different evolutions of air-sea interaction between El Niño Modoki I and II. It is seen clearly that the warm SST anomaly intensities during developing spring of El Niño Modoki I are significantly larger than those of El Niño Modoki II, which is similar to 

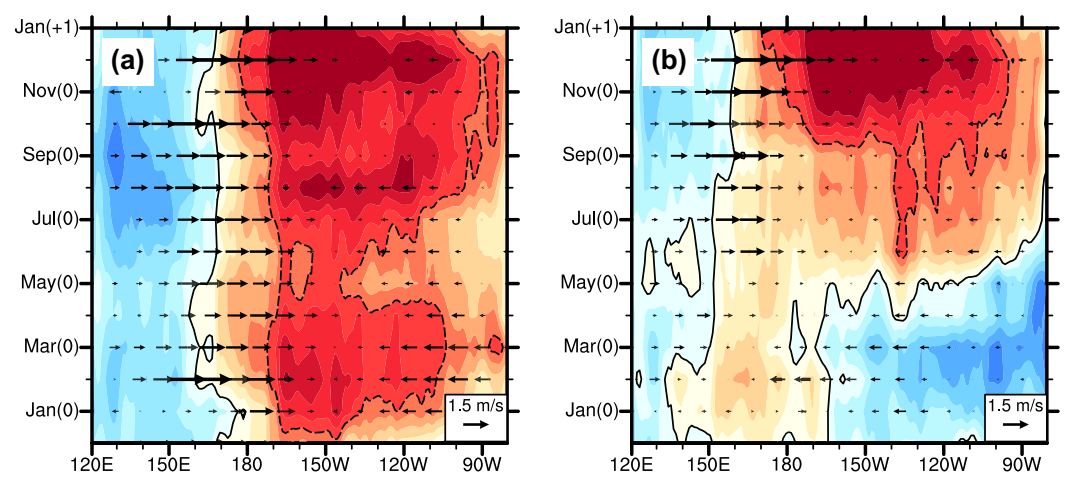

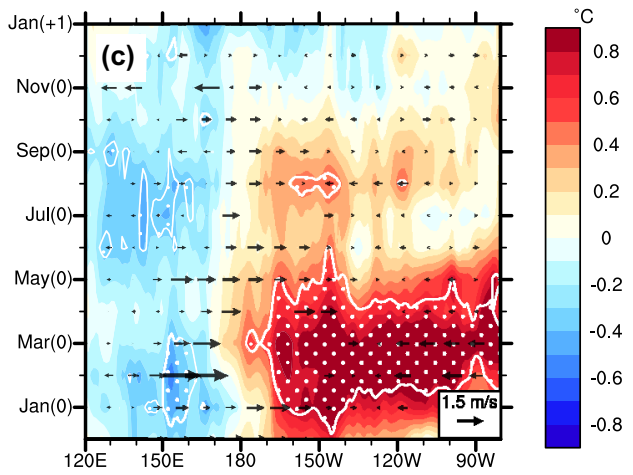

Fig. 1 The evolution of meridional-averaged $\left(5^{\circ} \mathrm{S}-5^{\circ} \mathrm{N}\right) 10-\mathrm{m}$ wind (vector, unit: $\mathrm{m} / \mathrm{s}$ ) and SST (shading, unit: ${ }^{\circ} \mathrm{C}$ ) anomalies during $\mathrm{El}$ Niño Modoki I (a), El Niño Modoki II (b) and their difference (c). (0) and (+1) in Y-axis indicate the developing and decaying years of El Niño Modoki I and II. Solid and dashed lines in $\mathbf{a}$ and $\mathbf{b}$ denote
$0{ }^{\circ} \mathrm{C}$ and $0.5^{\circ} \mathrm{C}$ contour lines for SST anomalies, respectively. White dotted areas in c represent SST anomaly differences exceeding $90 \%$ significance level based on Student's t test. Only wind differences that exceed $90 \%$ significance level are plotted in c previous studies (Wang and Wang 2013; Wang et al. 2018). It is also indicated that El Niño Modoki I appears earlier than El Niño Modoki II. The other distinct differences between El Niño Modoki I and II are that the westerly anomalies in the western and central tropical Pacific during developing spring of El Niño Modoki I are larger than those of El Niño Modoki II. That is, the warm SST anomalies in the central tropical Pacific during the developing year of El Niño Modoki II can be developed even with weak westerly wind anomalies in the western tropical Pacific. Here, a question is raised regarding how warm SST anomalies in the central Pacific occur during the developing spring and summer of El Niño Modoki II.

To investigate how warm SST anomalies evolve during various El Niño Modoki events, the tendency of the mixed-layer temperature in the Niño-4 region $\left(5^{\circ} \mathrm{S}-5^{\circ} \mathrm{N}\right.$, $160^{\circ} \mathrm{E}-150^{\circ} \mathrm{W}$ ) and associated physical processes are analyzed. During boreal spring and summer (February-March-April-May-June, FMAMJ) of El Niño Modoki $\mathrm{I}$, zonal advection $\left(-\mathrm{uT}_{\mathrm{x}}\right)$ is a major contributor to warm anomalies in the Niño-4 region, according to the mixedlayer temperature budget analysis (Fig. 2a). This is consistent with previous studies suggesting that zonal advection is the principal contributor (Kug et al. 2009, 2010; Yu et al. 2010; Capotondi et al. 2015). The contribution of zonal advection is twice as much as those of meridional advection. The meridional and vertical advections in mixed-layer temperature change account for approximately $50 \%$ and $25 \%$ of the mixed-layer temperature change, respectively. The net surface heat flux is the damping term. Distinct from El Niño Modoki I, vertical advection $\left(-\mathrm{wT}_{\mathrm{z}}\right)$ dominates the SST anomaly tendency during the developing spring and summer of El Niño Modoki II (Fig. 2b). The contribution of vertical advection is as high as about $90 \%$, and is much larger than that of zonal advection (25\%) and meridional
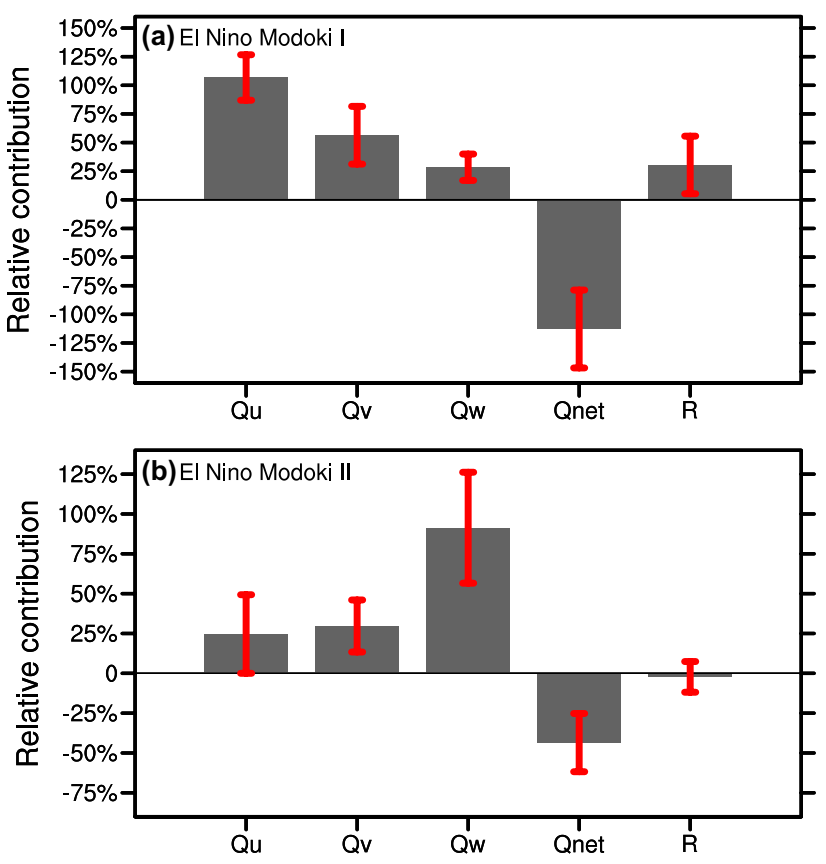

Fig. 2 Relative contributions of physical processes to the mixed-layer temperature tendency in Niño-4 region during the developing FMAMJ of El Niño Modoki I (a) and El Niño Modoki II (b). Qu, Qv and $\mathrm{Qw}$ represent the anomalous zonal advection term $\left(\mathrm{u} \frac{\partial \mathrm{T}}{\partial \mathrm{x}}\right)^{\prime}$, anomalous meridional advection term $\left(\mathrm{v} \frac{\partial \mathrm{T}}{\partial \mathrm{y}}\right)^{\prime}$, and anomalous vertical advection term $\left(\mathrm{w}_{\mathrm{e}} \frac{\partial \mathrm{T}}{\partial \mathrm{z}}\right)^{\prime}$, respectively. Qnet represents anomalous net surface heat flux, and $\mathrm{R}$ represents the residuals. Error bars indicate standard error of each term

advection (30\%). The net surface heat flux during El Niño Modoki II acts as a damping term as well.

This study focuses on vertical advection during the developing FMAMJ of El Niño Modoki II since the importance 
of horizontal advection on the development of the El Niño Modoki (so-called El Niño Modoki I in this study) has been revealed by many researchers (Kug et al. 2009, 2010; Yu et al. 2010; Capotondi et al. 2015). Vertical advection during El Niño Modoki II is further decomposed into four terms: subsurface temperature anomalies $\left(-\overline{\mathrm{w}} T_{\mathrm{z}}^{\prime}\right)$, upwelling anomalies $\left(-\mathrm{w}^{\prime} \overline{\mathrm{T}}_{\mathrm{z}}\right)$ and two nonlinear terms of $\left(-\mathrm{w}^{\prime} \mathrm{T}_{\mathrm{z}}^{\prime}\right)$ and $\left(\overline{\mathrm{w}^{\prime} \mathrm{T}_{\mathrm{z}}^{\prime}}\right)$. Their contributions to temperature tendencies are shown in Fig. 3. The two former terms indicate thermocline feedback and Ekman feedback, respectively. It is shown that the amplitude of the Ekman feedback is the largest, which dominates the changes of vertical advection term, and the

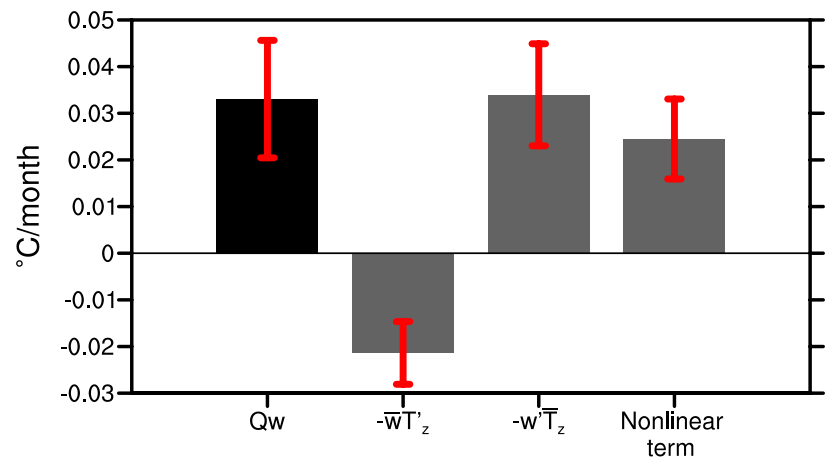

Fig. 3 Contributions of physical processes to the anomalous vertical advective term $(\mathrm{Qw})$ in Niño-4 region during the developing FMAMJ of El Niño Modoki II. $-\overline{\mathrm{wT}}_{\mathrm{z}}^{\prime}$ is the thermocline feedback term, $-\mathrm{w}^{\prime} \overline{\mathrm{T}}_{\mathrm{z}}$ is the Ekman feedback term, and nonlinear term represents the summation of nonlinear terms $\left(-w^{\prime} T^{\prime}+\overline{w^{\prime} T^{\prime}}\right)$. Error bars indicate standard error of each term nonlinear term takes on a secondary role. The thermocline feedback is negative, indicating that it is unfavorable for El Niño Modoki II development. It is illustrated that oceanic dynamic processes in the vertical direction are much more important than thermal stratification changes for SSTA warming during the onset of El Niño Modoki II.

\section{The possible mechanism for the onset of El Niño Modoki II}

The heat budget analysis indicates that the contribution of vertical advection to SST tendency in the central tropical Pacific is larger than that of horizontal advection during El Niño Modoki II. The physical processes leading to the large contribution of vertical advection are examined in this section, and a possible mechanism of El Niño Modoki II onset is proposed. Under climatological mean condition, trade winds and the geostrophic effect lead to the poleward flow of the upper layer water in the central equatorial Pacific, inducing the upwelling motions in the central tropical Pacific (Fig. 4a). In the climatological mean state, divergences of upper-layer currents are seen in central and eastern tropical Pacific from $180^{\circ} \mathrm{E}$ to $140^{\circ} \mathrm{W}$ (Fig. 4b). During the developing FMAMJ of El Niño Modoki II, downwelling anomalies weakening climatological upwelling motions at the equator appear (Fig. 4c), which is in agreement with the heat budget analysis shown above (Figs. 2b, 3). Moreover, the downwelling anomalies can extend as deep as $150 \mathrm{~m}$ near equator, which is the mean depth of thermocline. Therefore, the
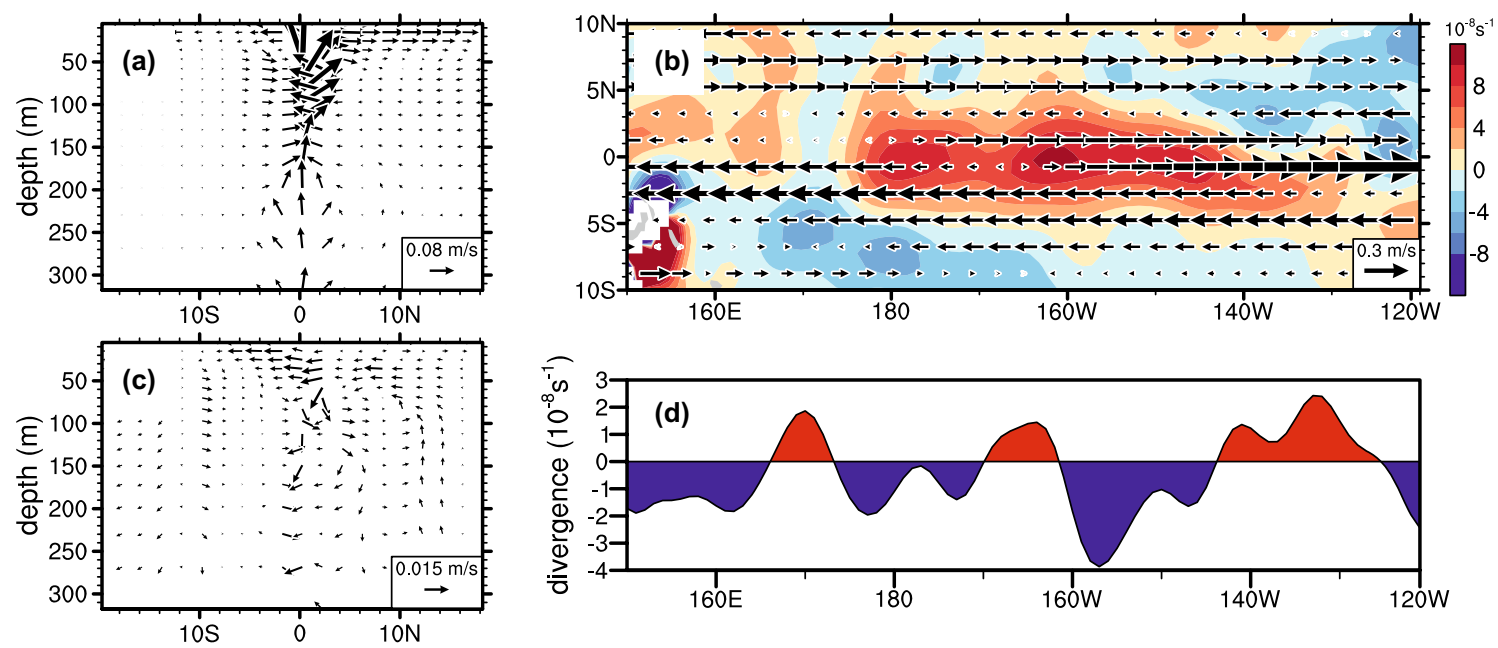

Fig. 4 Climatology of circulations (a, b) and the anomalous circulation during the developing FMAMJ of El Niño Modoki II (c, d) in the tropical Pacific. a Climatology of meridional and vertical velocity averaged in $160^{\circ} \mathrm{E}-150^{\circ} \mathrm{W}$ during FMAMJ. b Climatology of vertically averaged (above the thermocline) horizontal velocity (vector) and its divergence (shading) in FMAMJ. c Composites of meridi- onal and vertical velocity anomalies averaged in $160^{\circ} \mathrm{E}-150^{\circ} \mathrm{W}$ during the developing FMAMJ of El Niño Modoki II. d Composites of divergence anomalies (above the thermocline) in the tropics (averaged between $5^{\circ} \mathrm{S}-5^{\circ} \mathrm{N}$ ) during the developing FMAMJ of El Niño Modoki II. Here, vertical velocity in a and $\mathbf{c}$ are amplified $10^{4}$ times 
wind-induced oceanic currents above the thermocline and divergences are investigated in the followings. From Fig. 4c, it is seen that downwelling motion anomalies are associated with southward current anomalies in the upper layer of the Northern Hemisphere, indicating decreases in the subtropical cell (STC). Figure 4d displays equatorial-averaged $\left(5^{\circ} \mathrm{S}\right.$ and $\left.5^{\circ} \mathrm{N}\right)$ divergence anomalies during the developing FMAMJ of El Niño Modoki II. The anomalous convergence of the current velocities appears in most parts of the central tropical Pacific, with a maximum around $160^{\circ} \mathrm{W}$ (Fig. $4 \mathrm{~d}$ ). Anomalous convergence at the upper layer, induced by horizontal currents, can lead to weakened upwelling at the equator and less cold water upwelled into the mixed layer. Hence, SST anomalies tend to be warm.

Since oceanic surface circulations are significantly influenced by wind stress changes (Luo et al. 2015), wind stress anomalies in the developing spring of El Niño Modoki I and El Niño Modoki II are investigated (Fig. 5). The significant westerly wind stress anomalies are seen in the western and central tropical Pacific during developing FMAMJ of El Niño Modoki I accompanying with significant easterly wind stress anomalies in the eastern tropical Pacific (Fig. 5a). Different from El Niño Modoki I, westerly wind stress anomalies are weak at the equator during FMAMJ of El Niño Modoki II. Instead, anomalously strong westerly wind stress is seen in the northern subtropical Pacific $\left(10^{\circ} \mathrm{N}-20^{\circ} \mathrm{N}\right.$, blue box in Fig. 5b), which is associated with cyclonic anomalies in the northern subtropical Pacific (Yu et al. 2010; Yeh et al. 2015). In addition, strong easterly wind stress is found in the central-eastern tropical Pacific between $160^{\circ} \mathrm{W}$ and $130^{\circ} \mathrm{W}$ for El Niño Modoki II (green box in Fig. 5b), which is consistent with the evolution of surface winds shown in Fig. 1. The location of the significant easterly wind stress anomalies for El Niño Modoki II is more westward than those of El Niño Modoki I.

To examine whether the wind stress anomalies in the northern subtropical Pacific and eastern tropical Pacific in Fig. $5 \mathrm{~b}$ can result in the changes in upper-layer circulation and decreases in divergent flow, several numerical experiments based on a 2.5-layer model are conducted. A control run experiment and three sensitivity experiments are designed (Table 1). The model domain covers the Pacific $\left(40^{\circ} \mathrm{S}-40^{\circ} \mathrm{N}, 120^{\circ} \mathrm{E}-103^{\circ} \mathrm{W}\right)$. In the control run, the model is forced by the climatological zonal wind stress field for 50 years to reach a quasi-steady state. All three sensitivity experiments were restarted from the final state of the control run; in addition, the model was forced by different wind stress for 3 months.

The zonal wind stress used in the control run is shown in Fig. 6. It exhibits a saddle-shaped double-peak distribution in the meridional direction. Easterlies between $35^{\circ} \mathrm{S}$ and $30^{\circ} \mathrm{N}$ reach a maximum of $-0.06 \mathrm{~N} / \mathrm{m}^{2}$ and $-0.09 \mathrm{~N} / \mathrm{m}^{2}$ at
Fig. 5 Composites of wind stress anomalies (vector) during the developing FMAMJ of El Niño Modoki I (a) and El Niño Modoki II (b). Zonal wind stress anomalies (unit: $\mathrm{N} / \mathrm{m}^{2}$ ) exceeding $90 \%$ significance level are shaded. The wind stress anomalies enclosed by blue and green boxes are used in the sensitivity experiments of the 2.5-layer model

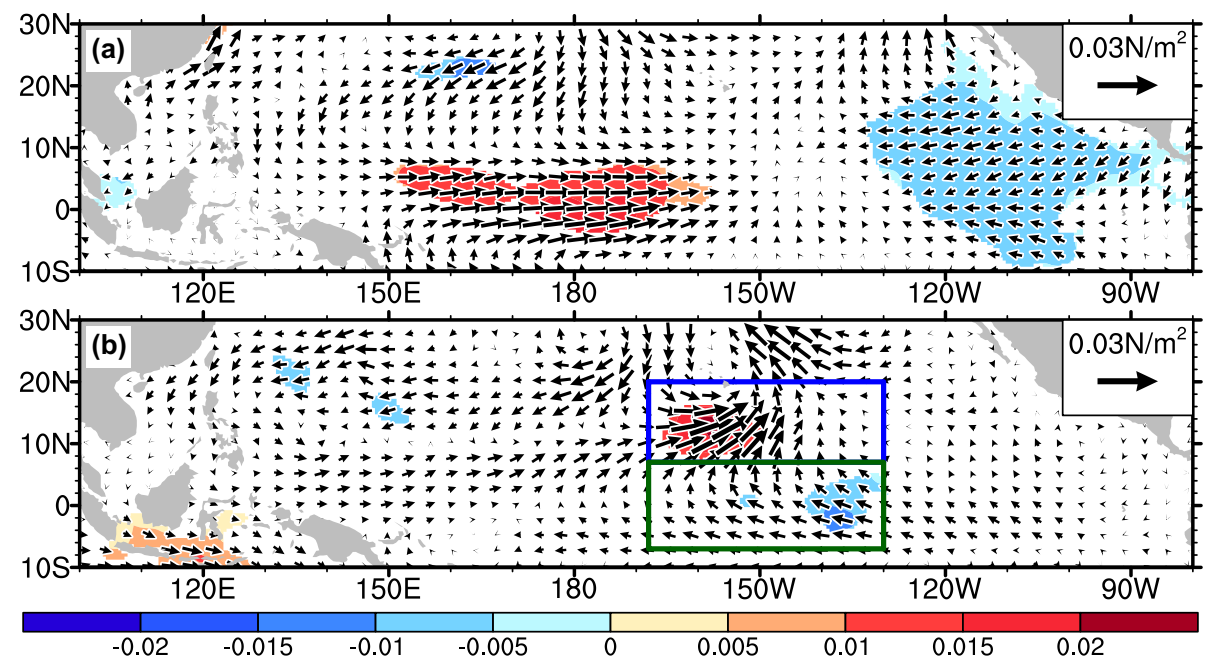

Table 1 The control run and three sensitivity experiments conducted in the 2.5-layer model

\begin{tabular}{ll}
\hline Experiment names & Wind stress forcing \\
\hline Control run & Zonal mean climatology \\
Subtropical force (SF) experiment & Zonal mean climatology plus wind stress anomalies in the blue box in Fig. 5 \\
Tropical force (TF) experiment & Zonal mean climatology plus wind stress anomalies in the green box in Fig. 5 \\
Subtropical and tropical force (STF) experiment & $\begin{array}{l}\text { Zonal mean climatology plus wind stress anomalies in the blue box and green } \\
\text { box in Fig. 5 }\end{array}$ \\
\hline
\end{tabular}


$20^{\circ} \mathrm{S}$ and $15^{\circ} \mathrm{N}$, respectively, and a minimum of $-0.025 \mathrm{~N} /$ $\mathrm{m}^{2}$ at the equator. Figure 7 shows the quasi-steady state at the end of the control run experiment. Due to the easterly wind, water piles up in the west part of the basin, leading to the west-east upward slope of thermocline. The thermocline depth is more than $160 \mathrm{~m}$ at the western boundary and less than $60 \mathrm{~m}$ at the eastern boundary (Fig. 7a), which is similar to the long-term mean state from reanalysis data. The subtropical gyres in both hemispheres and the equatorial counter-currents are reproduced in the control run (Fig. 7b). Thus, the model is capable of simulating the relationship between wind stress and upper layer circulation in the Pacific.

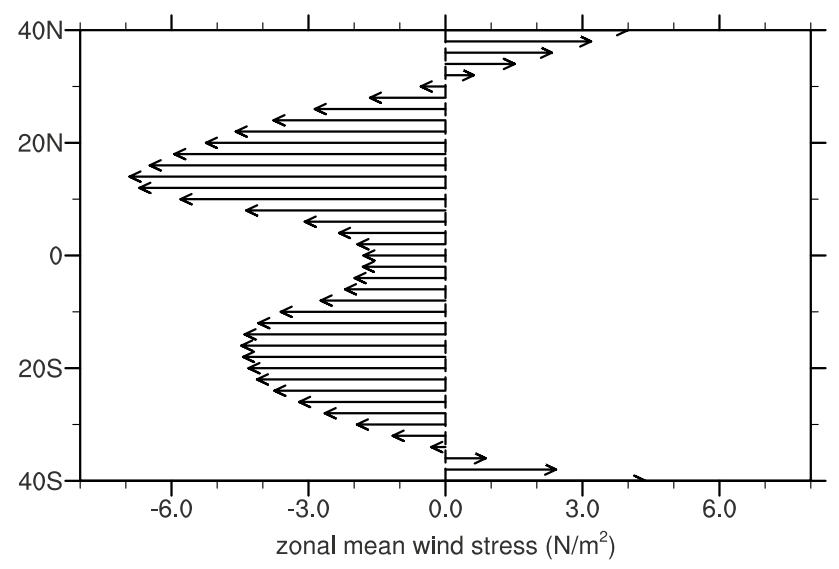

Fig. 6 Climatological mean of zonally-averaged $\left(120^{\circ} \mathrm{E}-103^{\circ} \mathrm{W}\right)$ zonal wind stress in FMAMJ
Three sensitivity experiments, referred to as the subtropical force (SF) experiment, tropical force (TF) experiment and subtropical and tropical force (STF) experiment (Table 1), are conducted. In these sensitivity experiments, the model is forced by the climatological zonal wind stress, plus wind stress anomalies in the blue box, green box and both boxes shown in Fig. 5b, respectively. The differences in ocean velocity above the thermocline and its divergence between the sensitivity experiments and the control run are shown in Fig. 8. In the SF experiment, the strong equatorward current anomalies from the subtropical regions to the tropics appear around $150^{\circ} \mathrm{W}$, which are associated with anomalous divergence centered in the subtropical Pacific and anomalous convergence centered near the tropical Pacific (around $150^{\circ} \mathrm{W}$ ) (Fig. $8 \mathrm{a}$ ). That is, the anomalous westerly wind stress in the northern subtropical Pacific can induce current anomalies equatorward in the upper layer and weaken the STC, which is similar to those inferred from reanalysis (Fig. 4c). Such equatorward flow anomalies result in anomalous convergence in the upper layer of the tropical Pacific near $150^{\circ} \mathrm{W}$ (Fig. 8d), and reduce climatological divergences over there. Hence, the results of the SF experiment suggest that wind stress in the northern subtropical Pacific (blue box in Fig. 5b) can induce anomalous convergence in the tropical Pacific through weakening the STC. For the TF experiment, anomalous westward currents associated with wind stress anomalies in the central-eastern tropical Pacific (Fig. 5b) are seen in the tropics from $160^{\circ} \mathrm{W}$ to $120^{\circ} \mathrm{W}$. The maximum of westward current anomalies located near $150^{\circ} \mathrm{W}$ induces the anomalous convergence and
Fig. 7 Simulated thermocline depth (a), and vertically-averaged (above the thermocline) horizontal velocity (vector) and its divergence (shading) (b) in control run of the 2.5-layer model

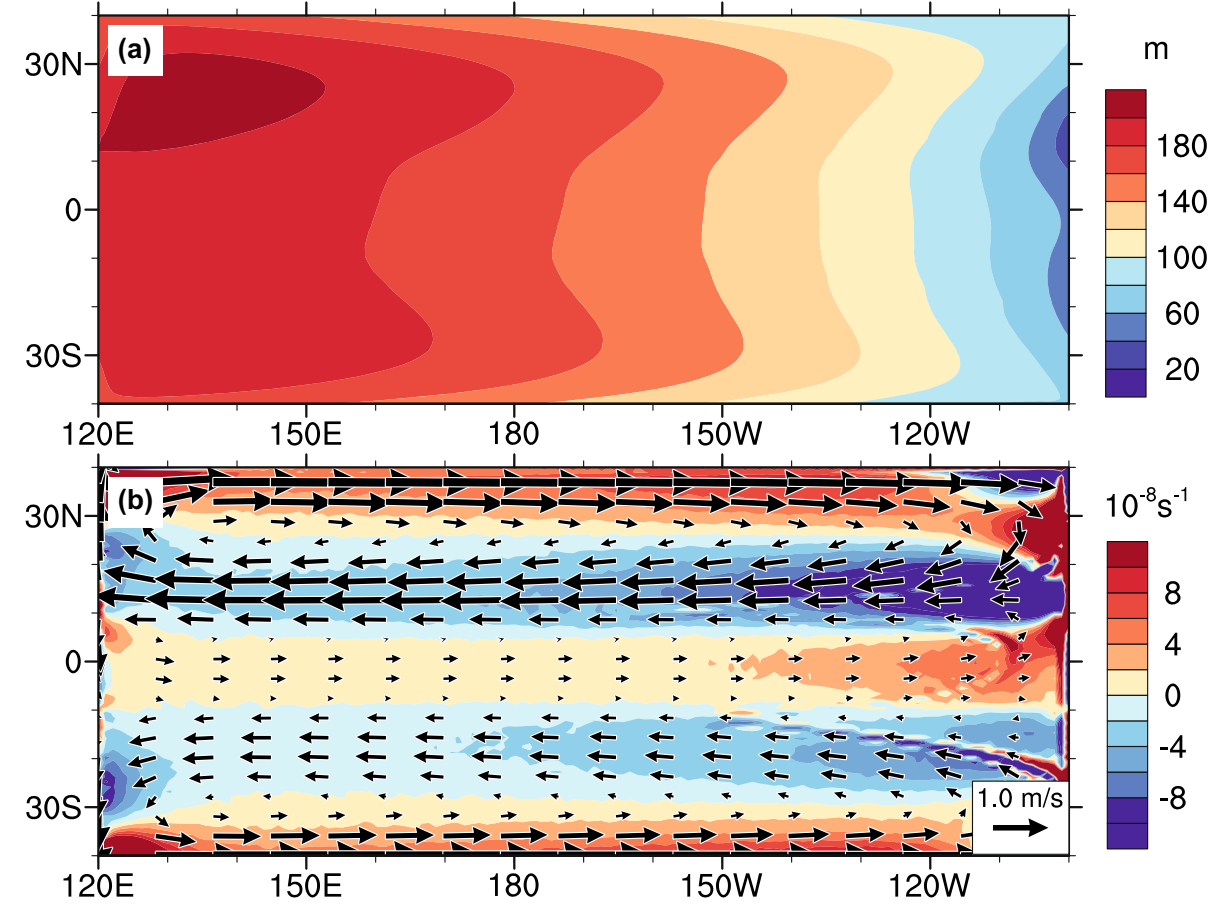



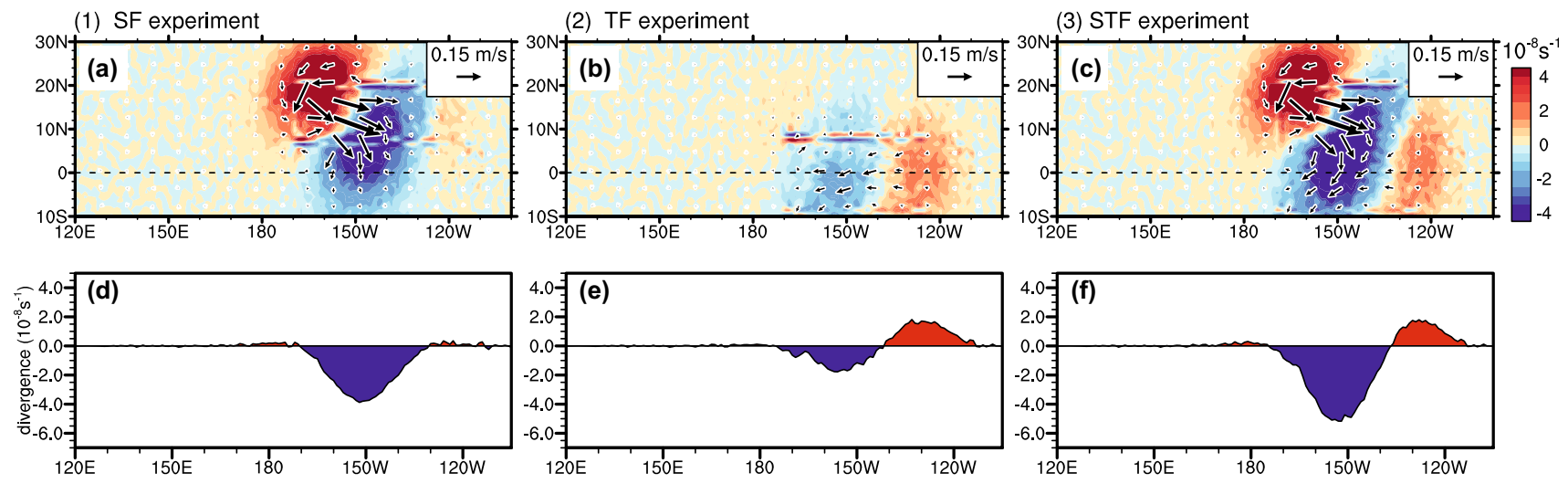

Fig. 8 The differences of velocity anomalies (vector) and divergence anomalies (shading) (upper panels), and the meridional-mean $\left(5^{\circ} \mathrm{S}-\right.$ $5^{\circ} \mathrm{N}$ ) divergence (lower panels) above the thermocline between the three sensitivity experiments and the control run. The left $(\mathbf{a}, \mathbf{d})$, mid- dle $(\mathbf{b}, \mathbf{e})$ and right $(\mathbf{c}, \mathbf{f})$ panels represent the subtropical force (SF) experiment, tropical force (TF) experiment and subtropical and tropical forces (STF) experiment, respectively

than that induced by the equatorial easterlies (Fig. 8d, e). It is indicated that the subtropical westerlies play more important role in development of El Niño Modoki II. Therefore, only the influences of the westerly anomalies in the northern subtropical Pacific are checked in the coupled model experiments.

After 1200 model years of fully coupled running under pre- industrial conditions, the wind stresses from the Coordinated Ocean-Ice Reference Experiments version 2 (COREv2) normal year forcing (Large and Yeager 2004) are used to force ocean in model. Here, the wind stresses are varied on monthly climatological. The simulation is 100 years, and is referred to as the control run. The sensitive experiment is identical to the control run except that the wind stress is imposed by the subtropical (Fig. 5b, blue box) westerly anomaly composites of El Niño Modoki II from January to June. The sensitive experiment is run for 100 years. The last 30 years simulations of control run and sensitive experiment are used in our study. The differences between control run and sensitive experiment could represent the influences of wind stress in northern subtropical Pacific.

Figure 9 displays the annual mean SST in the last 30 years of the control run. The distribution of SST in Pacific is well reproduced although there is the cold tongue bias, which is common limitation in current climate model performances ( $\mathrm{Li}$ and Xie 2012; Zheng et al. 2012). The differences between sensitive experiment and control run during April and June are shown in Fig. 10. Under the forcing of wind stress in northern subtropical Pacific, the significant warm SST anomalies are seen in the central and eastern tropical Pacific and extending to subtropical Pacific (Fig. 10a), which is similar to the SST anomalies pattern of El Nino Modoki II suggested by Wang and Wang (2013) and Wang et al. (2018). These warm SST anomalies are associated subtropical westerlies in the 2.5-layer model is twice larger 


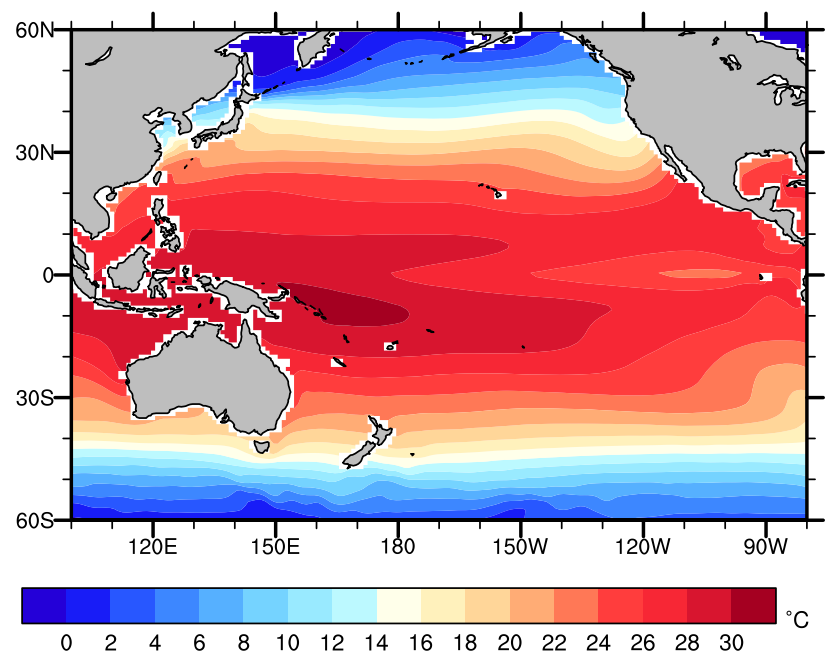

Fig. 9 Simulation of annual mean SST in control run of CESM1

with upper-layer oceanic circulation (Fig. 10a, b). There are equatorward currents at upper-layer along $180^{\circ} \mathrm{E}-160^{\circ} \mathrm{W}$, and the downwelling motions are obvious near the equator (Fig. 10b), which is similar to the observation in Fig. 4c. It is noted that since the anomalous westerlies are imposed in the North Pacific, the responses of meridional circulations in the southern hemisphere are weak. The westerly anomalies in the subtropical Pacific can induce the upper-layer westward current anomalies in $\left(160^{\circ} \mathrm{E}-160^{\circ} \mathrm{W}, 0-10^{\circ} \mathrm{N}\right)$, and the convergence of currents are around $\left(180^{\circ} \mathrm{E}-160^{\circ} \mathrm{W}, 0-10^{\circ} \mathrm{N}\right)$. Thus, it is confirmed by the coupled model that the westerly anomalies in the northern subtropical Pacific may enhance the equatorward currents in the central tropical Pacific, and then result in the downwelling anomalies and current convergences at upper-layer, which are favorable for warm SST anomaly appearances.

\section{Summary and discussion}

The evolution of coupled SST and surface wind anomalies in the equatorial Pacific during El Niño Modoki I and El Niño Modoki II events defined by Wang and Wang (2013) are analyzed and compared in this study. In the El Niño Modoki I, westerly wind anomalies appear earlier than warm SST anomalies in the equatorial Pacific, which is in agreement with previous studies; thus, anomalous westerlies in the western Pacific play a key role in triggering El Niño Modoki by extending the warm pool eastward (Chen et al. 2015; Lai et al. 2015). However, SST anomalies might be positive, even in the absence of strong westerly anomalies in the western tropical Pacific during El Niño Modoki II. In addition, easterly anomalies are accompanied by warm SST anomalies in the central tropical Pacific. These differences in SSTs and surface wind evolutions suggest that the dynamical progression of El Niño Modoki II is different from those of El Niño Modoki I.

The heat budget analysis of the mixed layer temperature in the Niño-4 region during the El Niño Modoki II developing phase shows that Ekman feedback is a major contributor to the warming SST tendency in the central tropical Pacific, which is quite different from that of El Niño Modoki I. Yang and Zhang (2008) also emphasized the important role of the anomalous upwelling in modulating the ENSO variability. Our analysis further suggests that the Ekman feedback is substantially related to wind stress anomalies in the northern subtropical Pacific and the central-eastern tropical Pacific. From reanalysis datasets and model experiments, subtropical westerly and equatorial easterly wind stress anomalies can influence mixed-layer flow and result in anomalous convergence in the central equatorial Pacific. A schematic diagram is displayed to summarize the proposed El Niño Modoki II mechanism (Fig. 11). Subtropical wind stress anomalies lead to Ekman transport towards the equator, and equatorial wind
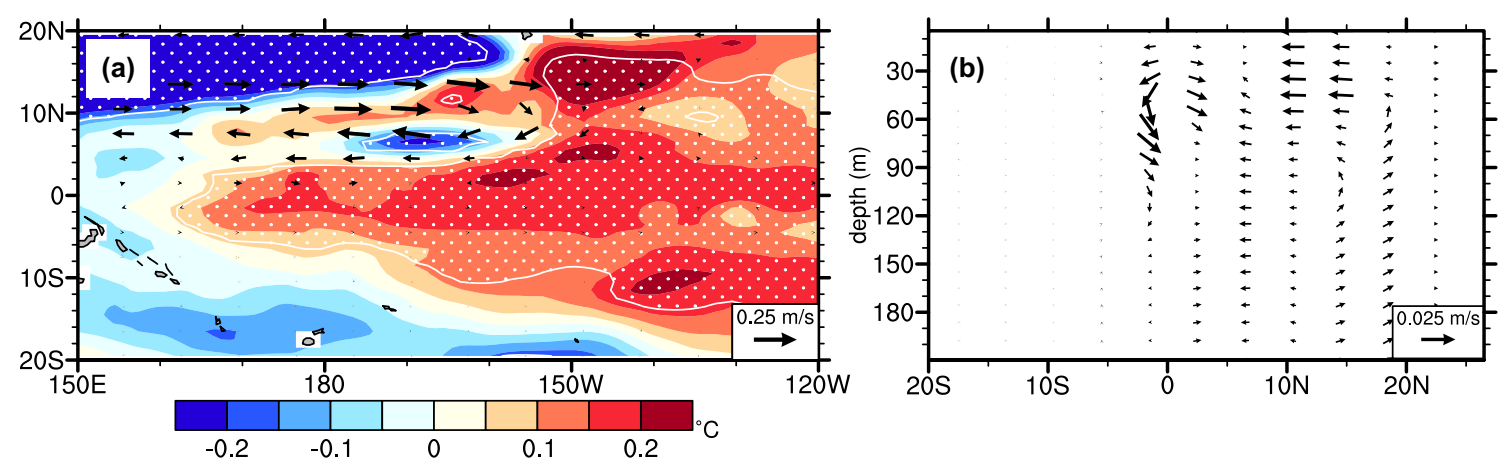

Fig. 10 Differences of a SST (shading) and upper $50 \mathrm{~m}$ velocity (vector), and b meridional and vertical velocity along $180^{\circ} \mathrm{W}-160^{\circ} \mathrm{W}$ during April and June between the sensitive experiment and the control run of CESM1. White dotted areas indicate SST differences exceeding 95\% significance level, and black vectors indicate velocity differences exceeding $95 \%$ significance level in a. Vertical velocity differences in $\mathbf{b}$ are amplified $10^{4}$ times 


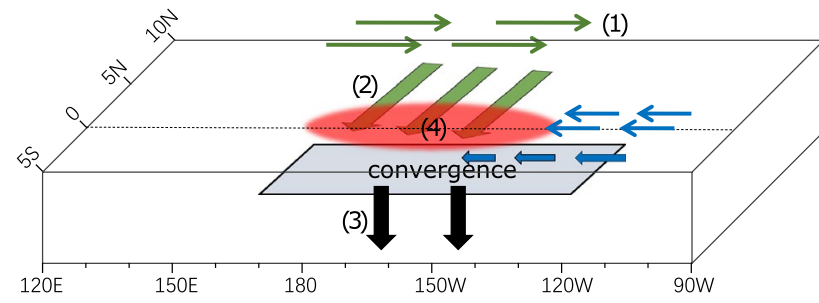

Fig. 11 A schematic diagram illustrating the appearance of warm SST anomalies in the central tropical Pacific during El Niño Modoki II induced by anomalous westerly anomalies in the northern subtropical Pacific and easterly anomalies in the eastern tropical Pacific. The green and blue thin arrows (1) depict anomalous westerly anomalies in the northern subtropical Pacific and easterly anomalies in the eastern tropical Pacific, respectively. The green and blue bold arrows (2) depict anomalous equatorward currents and westward currents in the upper layer resulting from (1). Black bold arrows (3) show the anomalous downwelling motion induced by anomalous convergence at the surface. The red area at the sea surface (4) indicates warming SST

stress anomalies increase westward current anomalies. These current anomalies weaken climatological divergent flow in the upper layer in the central tropical Pacific. The weakening of the divergent flow decreases upwelling at the equator, and tends to warm SST in the central equatorial Pacific.

This study reveals the influence of surface wind in the northern subtropical Pacific and central-eastern equatorial Pacific on mixed-layer temperature changes in the central tropical Pacific during the onset of El Niño Modoki II. This is different from previous studies regarding subtropical-tropical interplays. Gu and Philander (1997) and Kleeman and Klinger (1999) emphasized temperature changes or water transports associated with the Pacific STC that modulate ENSO on interdecadal and decadal scales. However, in this study, we focus on the dynamic effect of subtropical and equatorial wind stress anomalies on the modulation of diverse El Niño events on an interannual scale. In addition, different from the WES feedback mechanism that involves the propagation of SST anomalies and wind anomalies (Vimont et al. 2009; Zhang et al. 2009; Yu et al. 2010; Lu et al. 2017), the impacts of ocean dynamics are emphasized in this study. A coupled model may be needed to further investigate the detail of the SST evolution during the onset of El Niño Modoki II, as well as the subsequent progression afterwards.

This study illustrates the roles of wind stress anomalies in the northern subtropical Pacific and the central-eastern tropical Pacific on the El Niño Modoki II onset. However, the causes of these wind stress anomalies remain unknown. It is speculated that the wind stress anomalies in the northern subtropical Pacific and the central-eastern tropical Pacific may be related to variations in the North Pacific Oscillation (NPO, Yeh et al. 2015) and the southern Pacific/tropical Atlantic (Ham et al. 2013a, b), respectively. These questions will be analyzed in future studies.
Acknowledgements This work was supported by the Strategic Priority Research Program of Chinese Academy of Sciences (Grant no. XDA20060502), National Key R\&D Program of China (2017YFA0603200), and the National Natural Science Foundation of China (Grant Nos. 41422601, 41876021). Support for the Twentieth Century Reanalysis Project dataset is provided by the U.S. Department of Energy, Office of Science Innovative and Novel Computational Impact on Theory and Experiment (DOE INCITE) program, and Office of Biological and Environmental Research (BER), and by the National Oceanic and Atmospheric Administration Climate Program Office.

Open Access This article is distributed under the terms of the Creative Commons Attribution 4.0 International License (http://creativeco mmons.org/licenses/by/4.0/), which permits unrestricted use, distribution, and reproduction in any medium, provided you give appropriate credit to the original author(s) and the source, provide a link to the Creative Commons license, and indicate if changes were made.

\section{References}

Ashok K, Behera SK, Rao SA et al (2007) El Niño Modoki and its possible teleconnection. J Geophys Res Ocean 112:1-27. https:// doi.org/10.1029/2006JC003798

Bjerknes J (1969) Atmospheric teleconnections from the equatorial Pacific. Mon Weather Rev 97:163-172. https:// doi.org/10.1175/1520-0493(1969)097\%3C0163:ATFTE P\%3E2.3.CO;2

Capotondi A, Wittenberg AT, Newman M et al (2015) Understanding ENSO diversity. Bull Am Meteorol Soc 96:921-938

Carton JA, Giese BS (2008) A reanalysis of ocean climate using simple ocean data assimilation (SODA). Mon Weather Rev 136:2999 3017. https://doi.org/10.1175/2007MWR1978.1

Chen D, Lian T, Fu C et al (2015) Strong influence of westerly wind bursts on El Niño diversity. Nat Geosci 8:339-345. https://doi. org/10.1038/ngeo2399

Compo GP, Whitaker JS, Sardeshmukh PD et al (2011) The twentieth century reanalysis project. Q J R Meteorol Soc 137:1-28. https:// doi.org/10.1002/qj.776

Fedorov AV, Hu S, Lengaigne M et al (2015) The impact of westerly wind bursts and ocean initial state on the development, and diversity of El Niño events. Clim Dyn 44(5-6):1381-1401

Giese BS, Ray S (2011) El Niño variability in simple ocean data assimilation (SODA), 1871-2008. J Geophys Res 116:C02024

Graham FS, Wittenberg AT, Brown JN et al (2017) Understanding the double peaked El Niño in coupled GCMs. Clim Dyn 48:20452063. https://doi.org/10.1007/s00382-016-3189-1

Gu D, Philander SGH (1997) Interdecadal climate fluctuations that depend on exchanges between the tropics and extratropics. Science 275(5301):805

Ham YG, Kug JS, Park JY, Jin FF (2013a) Sea surface temperature in the north tropical Atlantic as a trigger for El Niño/Southern Oscillation events. Nat Geosci 6(2):112-116

Ham YG, Kug JS, Park JY (2013b) Two distinct roles of Atlantic SSTs in ENSO variability: north tropical Atlantic SST and Atlantic Niño. Geophys Res Lett 40(15):4012-4017

Hu S, Fedorov AV, Lengaigne M, Guilyardi E (2014) The impact of westerly wind bursts on the diversity and predictability of El Niño events: an ocean energetics perspective. Geophys Res Lett 41:4654-4663

Huang RX (1987a) A three-layer model for wind-driven circulation in a subtropical subpolar basin. Part I: model formulation and the subcritical state. J Phys Oceanogr 17(5):664-678 
Huang RX (1987b) A three-layer model for wind-driven circulation in a subtropical subpolar basin. Part II: the supercritical and hypercritical states. J Phys Oceanogr 17(5):679-697

Huang B, Xue Y, Zhang D et al (2010) The NCEP GODAS ocean analysis of the tropical pacific mixed layer heat budget on seasonal to interannual time scales. J Clim 23:4901-4925. https:// doi.org/10.1175/2010JCLI3373.1

Hurrell J et al (2013) The community earth system model: a framework for collaborative research. Bull Am Meteorol Soc 94:1339-1360

Kao HY, Yu JY (2009) Contrasting eastern-Pacific and central-Pacific types of ENSO. J Clim 22:615-632. https://doi.org/10.1175/2008J CLI2309.1

Kleeman R Jr, Klinger MC BA (1999) A mechanism for generating ENSO decadal variability. Geophys Res Lett 26(12):1743-1746

Kug JS, Jin FF, An S, Il (2009) Two types of El Niño events: cold tongue El Niño and warm pool El Niño. J Clim 22:1499-1515. https://doi.org/10.1175/2008JCLI2624.1

Kug JS, Choi J, An S, Il et al (2010) Warm pool and cold tongue El Niño events as simulated by the GFDL 2.1 coupled GCM. J Clim 23:1226-1239. https://doi.org/10.1175/2009JCLI3293.1

Kumar KK, Rajagopalan B, Hoerling M et al (2006) Unraveling the mystery of Indian monsoon failure during El Niño. Science 314(5796): 115

Lai AWC, Herzog M, Graf HF (2015) Two key parameters for the El Niño continuum: zonal wind anomalies and Western Pacific subsurface potential temperature. Clim Dyn 45:3461-3480. https ://doi.org/10.1007/s00382-015-2550-0

Large W, Yeager S (2004) Diurnal to decadal global forcing for ocean and sea-ice models: the data sets and flux climatologies. CGD Division of the National Center for Atmospheric Research, NCAR Technical Note NCAR/TN-460 + STR

Larkin NK, Harrison DE (2005) On the definition of El Niño and associated seasonal average U.S. weather anomalies. Geophys Res Lett 32:1-4. https://doi.org/10.1029/2005GL022738

Levitus S, Boyer TP (1994) World ocean atlas 1994 vol 4: temperature. NOAA Atlas NESDIS 4. U.S. Department of Commerce, Washington, DC

Li G, Xie S-P (2012) Origins of tropical-wide SST biases in CMIP multi-model ensembles. Geophys Res Lett 39:L22703

Lian T, Chen D (2012) An evaluation of rotated EOF analysis and its application to tropical Pacific SST variability. J Clim 25(1):5361-5373

Lian T, Chen D, Tang Y, Wu Q (2014) Effects of westerly wind bursts on El Niño: a new perspective. Geophys Res Lett 41:3522-3527

Liu QY, Wang D, Wang X, Shu Y, Xie Q, Chen J (2014) Thermal variations in the South China Sea associated with the eastern and central Pacific El Niño events and their mechanisms. J Geophys Res Oceans 119:8955-8972. https://doi.org/10.1002/2014JC010429

Liu L, Yang G, Zhao X et al (2017) Why was the Indian ocean dipole weak in the context of the extreme El Niño in 2015? J Clim 30(12):4755-4761

Lu F, Liu Z, Liu Y et al (2017) Understanding the control of extratropical atmospheric variability on ENSO using a coupled data assimilation approach. Clim Dyn 48:3139-3160. https://doi.org/10.1007/ s00382-016-3256-7

Luo Y, Lu J, Liu F et al (2015) Understanding the El Niño-like oceanic response in the tropical Pacific to global warming. Clim Dyn 45(7-8): 1945-1964

Neale RB et al (2012) Description of the NCAR community atmosphere model (CAM 5.0). NCAR Tech Note TN-486, p 274

Rayner NA, Parker DE, Horton EB, Folland CK, Alexander LV, Rowell DP, Kent EC, Kaplan A (2003) Global analyses of SST, sea ice and night marine air temperature since the late nineteenth century. J Geophys Res. https://doi.org/10.1029/2002JD002670

Saji NH, Goswami BN, Vinayachandran PN et al (1999) A dipole mode in the tropical Indian Ocean. Nature 401:360-363
Smith RD et al (2010) The parallel ocean program (POP) reference manual: ocean component of the community climate system model (CCSM) and community earth system model (CESM). Los Alamos National Laboratory Tech Rep LAUR-10-01853, p 141

Sprintall J, Tomczak M (1992) Evidence of the barrier layer in the surface layer of the tropics. J Geophys Res Ocean 97:7305-7316. https://doi.org/10.1029/92JC00407

Tan W, Wang X, Wang W, Wang C, Zuo J (2016) Different responses of sea surface temperature in the South China sea to various El Niño events during boreal autumn. J Clim 29:1127-1142. https:// doi.org/10.1175/JCLI-D-15-0338.1

Taschetto AS, England MH (2009) El Niño Modoki impacts on Australian rainfall. J Clim 22:3167-3174. https://doi.org/10.1175/2008J CLI2589.1

Trenberth KE, Stepaniak DP (2001) Indices of El Niño evolution. J Clim 14:1697-1701. https://doi.org/10.1175/15200442(2001)014\%3C1697:LIOENO\%3E2.0.CO;2

Vimont DJ, Alexander M, Fontaine A (2009) Midlatitude excitation of tropical variability in the Pacific: the role of thermodynamic coupling and seasonality. J Clim 22:518-534. https://doi. org/10.1175/2008JCLI2220.1

Wang C, Wang X (2013) Classifying El Niño Modoki I and II by different impacts on rainfall in southern China and typhoon tracks. J Clim 26:1322-1338. https://doi.org/10.1175/JCLI-D-12-00107.1

Wang X, Wang C (2014) Different impacts of various El Niño events on the Indian Ocean Dipole. Clim Dyn 42:991-1005. https://doi. org/10.1007/s00382-013-1711-2

Wang C, Li C, Mu M, Duan W (2013) Seasonal modulations of different impacts of two types of ENSO events on tropical cyclone activity in the western North Pacific. Clim Dyn 40:2887-2902. https://doi.org/10.1007/s00382-012-1434-9

Wang X, Zhou W, Li C, Wang D (2014) Comparison of the impact of two types of El Niño on tropical cyclone genesis over the South China Sea. Int J Climatol 34:2651-2660. https://doi.org/10.1002/ joc. 3865

Wang X, Tan W, Wang C (2018) A new index for identifying different types of El Niño Modoki events. Clim Dyn 50(7):2753-2765. https://doi.org/10.1007/s00382-017-3769-8

Weng H, Wu G, Liu Y et al (2011) Anomalous summer climate in China influenced by the tropical Indo-Pacific Oceans. Clim Dyn 36:769-782. https://doi.org/10.1007/s00382-009-0658-9

Xie S, Philander SGH (1994) A coupled ocean-atmosphere model of relevance to the ITCZ in the eastern Pacific. Tellus A 46:340-350

Xu K, Huang QL, Tam CY et al (2018) Roles of tropical SST patterns during two types of ENSO in modulating wintertime rainfall over southern China. Clim Dyn. https://doi.org/10.1007/s0038 2-018-4170-y

Yang H, Zhang Q (2008) Anatomizing the ocean's role in ENSO changes under global warming. J Clim 21(24):6539-6555

Yeh SW, Wang X, Wang C, Dewitte B (2015) On the relationship between the North Pacific climate variability and the Central Pacific El Niño. J Clim 28:663-677. https://doi.org/10.1175/ JCLI-D-14-00137.1

Yu JY, Kao HY (2007) Decadal changes of ENSO persistence barrier in SST and ocean heat content indices: 1958-2001. J Geophys Res Atmos 112:1-10. https://doi.org/10.1029/2006JD007654

Yu JY, Kao HY, Lee T (2010) Subtropics-related interannual sea surface temperature variability in the central equatorial pacific. J Clim 23:2869-2884. https://doi.org/10.1175/2010JCLI3171.1

Yu JY, Wang X, Yang S, Paek H, Chen M (2017) Changing El Niñosouthern oscillation and associated climate extremes. In: Wang SY, Yoon JH, Funk C, Gillies RR (eds) Climate extremes: patterns and mechanisms. AGU geophysical monograph series, vol 226. Wiley, American Geophysical Union, Hoboken, NJ, Washington, DC, pp 3-38 
Zhang Q, Kumar A, Xue Y et al (2007) Analysis of the ENSO cycle in the NCEP coupled forecast model. J Clim 20:1265-1284. https:// doi.org/10.1175/JCLI4062.1

Zhang L, Chang P, Ji L (2009) Linking the Pacific meridional mode to ENSO: coupled model analysis. J Clim 22:3488-3505. https:// doi.org/10.1175/2008JCLI2473.1
Zheng Y, Lin J-L, Shinoda T (2012) The equatorial Pacific cold tongue simulated by IPCC AR4 coupled GCMs: upper ocean heat budget and feedback analysis. J Geophys Res 117:C05024 